\title{
Brittle stars from the Lower Cretaceous of Patagonia: first ophiuroid articulated remains for the Mesozoic of South America
}

\author{
*Diana E. Fernández ${ }^{1,2}$, Luciana Giachetti', Sabine Stöhr³, Ben Thuy ${ }^{4}$, Damián E. Pérez \\ Marcos Comerio ${ }^{6}$, Pablo J. Pazos ${ }^{1,2}$
}

\author{
${ }^{1}$ Universidad de Buenos Aires, Facultad de Ciencias Exactas y Naturales, Departamento de Ciencias Geológicas, Buenos Aires, Argentina. \\ elizabeth@gl.fcen.uba.ar; giachetti.luciana@gmail.com;pazos@gl.fcen.uba.ar \\ ${ }^{2}$ CONICET-Universidad de Buenos Aires, Instituto de Estudios Andinos Don Pablo Groeber (IDEAN), Buenos Aires, Argentina. \\ ${ }^{3}$ Swedish Museum of Natural History, Department of Zoology, Box 50007, 10405 Stockholm, Sweden. \\ sabine.stohr@nrm.se \\ ${ }^{4}$ Natural History Museum Luxembourg, Department of Palaeontology, 25, rue Münster, 2160 Luxembourg-City, Luxembourg. \\ bthuy@mnhn.lu \\ ${ }_{5}^{5}$ Museo Argentino de Ciencias Naturales Bernardino Rivadavia, División Paleoinvertebrados, Av. Ángel Gallardo 470 (C1405DJR), \\ Buenos Aires, Argentina. \\ trophon@gmail.com \\ ${ }^{6}$ Centro de Tecnología de Recursos Minerales y Cerámica (CETMIC), Consejo Nacional de Investigaciones Cientificas y Técnicas \\ (CONICET), camino Centenario y 506 s/n, C.C.49 (B1897ZCA), M.B. Gonnet, Argentina. \\ comerio@gl.fcen.uba.ar \\ *Corresponding author: elizabeth@gl.fcen.uba.ar; arkhamdryad@gmail.com.
}

\begin{abstract}
The first articulated remains of ophiuroids for the Mesozoic of South America are described from the Lower Cretaceous of Neuquén Basin, Argentina. The taxonomic analysis allows the assignment of the material described herein to the extinct genus Ophiopetra. The specimens belong to a new species, but considering the poor preservation, a new name is not introduced, as it would be based on an incomplete diagnosis. Certain characteristics (e.g., the diameter of the disc, the width/height ratio of the vertebrae) suggest that these ophiuroids are paedomorphic specimens. In light of the latest classification of the Ophiuroidea, and new insights on the spine articulation microstructure of Ophiopetra lithographica presented herein, a transfer of Ophiopetra to the family Ophionereididae within the order Amphilepidida is proposed. This material expands the palaeogeographic record of this genus, since it represents the first remains of Ophiopetra described in the Southern Hemisphere. It is also the first Cretaceous record of the genus worldwide.
\end{abstract}

Keywords: Ophiuroidea, Early Cretaceous, Southern Hemisphere, Ophiopetra, Ophionereididae.

RESUMEN. Ofiuroideos del Cretácico Inferior de Patagonia: primer registro fósil articulado para el Mesozoico de América del Sur. Se describen los primeros registros fósiles de ofiuroideos articulados del Mesozoico de América del Sur, provenientes del Cretácico Inferior de Cuenca Neuquina, Argentina. El análisis taxonómico permite asignar el material descrito al género extinto Ophiopetra. Los especímenes pertenecen a una nueva especie, pero no se propone un nuevo nombre porque, debido a la pobre preservación, estaría basado en una diagnosis incompleta. Ciertas características (e.g., el diámetro del disco, la relación ancho/alto de vértebras, etc.) sugieren que estos ofiuroideos son especímenes pedomórficos. Se propone la transferencia de Ophiopetra a la familia Ophionereididae del orden Amphilepidida teniendo en cuenta la última clasificación de ofiuroideos y nuevas evidencias sobre la microestructura de las articulaciones espinales de Ophiopetra lithographica presentadas en este trabajo. Este material expande el registro paleogeográfico del género, ya que es la primera descripción de Ophiopetra en el hemisferio sur. Además, es el primer registro cretácico del género a nivel mundial. 


\section{Introduction}

Ophiuroids (Echinodermata: Ophiuroidea), commonly known as brittle stars, are a diverse group of echinoderms. Their extant representatives are cosmopolitan and contribute significantly to species diversity in many marine benthic communities (Gerdes et al., 1992; Dahm, 1996; Stöhr et al., 2012). Despite their early appearance in the Phanerozoic (Early Ordovician), the fossil record of ophiuroids is relatively scarce, mainly due to post-mortem disarticulation of their skeletal elements. Specimens with articulated and largely complete skeleton are extremely rare (Spencer and Wright, 1966; Aronson, 1989; Kerr and Twitchett, 2004; Martínez et al., 2010). Systematic assessment of fossil ophiuroids has recently received increasing attention (Ewin and Thuy, 2017). Yet, knowledge of the fossil record of ophiuroids, particularly in the Lower Cretaceous, is still limited (Thuy et al., 2014).

The ophiuroid fossil record in South America is scarce (Martin-Medrano and García-Barrera, 2013). Recently, ophiuroid remains were reported for the first time in the lowermost part of the Lower Cretaceous Agua de la Mula Member of the Agrio Formation, Neuquén Basin, Patagonia (Pérez et al., 2011). The purpose of this work is twofold: i. to present a detailed description of this material; and, ii. to provide a taxonomic assignment in the light of the latest classification of the Ophiuroidea. The material presented here represents the first articulated remains of ophiuroids for the Mesozoic of South America.

\section{Geological setting, study area and paleoenviron- mental context}

The Neuquén Basin (Fig. 1A) is located in westcentral Argentina (northern Patagonia) between $34^{\circ}$ and $41^{\circ} \mathrm{S}$. It contains marine and continental sedimentary deposits of Late Triassic to Paleogene age (Vergani et al., 1995; Legarreta and Uliana, 1999). Most of the Jurassic and Lower Cretaceous sedimentary deposits are composed of diverse, highly fossiliferous marine facies associated with transgressions (Howell et al., 2005). During the Early Cretaceous, the basin was connected to the paleoPacific Ocean to the west by a gateway, accentuated by a roughly $\mathrm{N}-\mathrm{S}$ oriented island arc chain, and the basin was affected by eustatic and relative sea level variations (Zapata and Folguera, 2005). Close to the Late Hauterivian, the Neuquén basin was rapidly flooded, and the basin-wide style of ramp deposition had resumed, represented by a calm open marine basin with deposition of organic-rich shales and mudstones (Legarreta and Uliana, 1991).

The Agrio Formation, in the Neuquén Basin, is the youngest unit of the Mendoza Group (TithonianBarremian), exposed in Neuquén Province (Weaver, 1931). The upper member, or Agua de la Mula Member (Leanza et al., 2001), of the Agrio Formation is late Hauterivian to early Barremian in age (Aguirre-Urreta et al., 2007, 2015; Aguirre-Urreta and Rawson, 2012). It comprises mixed carbonate-siliciclastic marine and marginal-marine deposits (Spalletti et al., 2001a; Lazo et al., 2005; Pazos and Fernández, 2010; Fernández and Pazos, 2012). The uppermost part of the unit was tidally influenced (Pazos et al., 2012; Fernández and Pazos, 2013), while the lowermost levels have been interpreted as an open marine ramp under fluctuating rates of siliciclastic input and carbonate productivity (Spalletti et al., 2001b; Comerio et al., 2018). This highly fossiliferous unit presents varied and abundant evidence of invertebrate fauna (e.g., Aguirre-Urreta, 2003; Cichowolski, 2003; Lazo et al., 2005, 2009; Rodríguez, 2007; Taylor et al., 2009; Aguirre-Urreta et al., 2011; Luci et al., 2013; Fernández and Pazos, 2013; Cataldo, 2014). However, ophiuroids were never before described in the unit. The bed of interest in this work is within the lowermost levels of the Agua de la Mula Member (Fig. 1B) at Loma La Torre (37 $19-20^{\prime} \mathrm{S}$, $69^{\circ} 50-51^{\prime} \mathrm{W}$ ), in the Neuquén Province (Fig. 1A). The ophiuroid-bearing bed is a mudstone level, located approximately $12 \mathrm{~m}$ above the contact with the underlying Avilé Member (Fig. 1B). The logged section comprises three main lithofacies: massive mudstones, marlstones, and laminated shales. In this section, two intervals are distinguished based on their lithology and stacking pattern. Within the first $10 \mathrm{~m}$, outcrops comprise moderately to highly indurated beds where mudstones and marlstones dominate over shales. In the second interval, shales dominate over mudstones and marlstones. In nearby localities, these two intervals were identified and have been interpreted as deposited in a distal to proximal outer ramp setting (Comerio et al., 2018). A similar paleoenvironmental interpretation is envisaged here. The ophiuroid-bearing level lies within the proximal outer ramp deposits. 


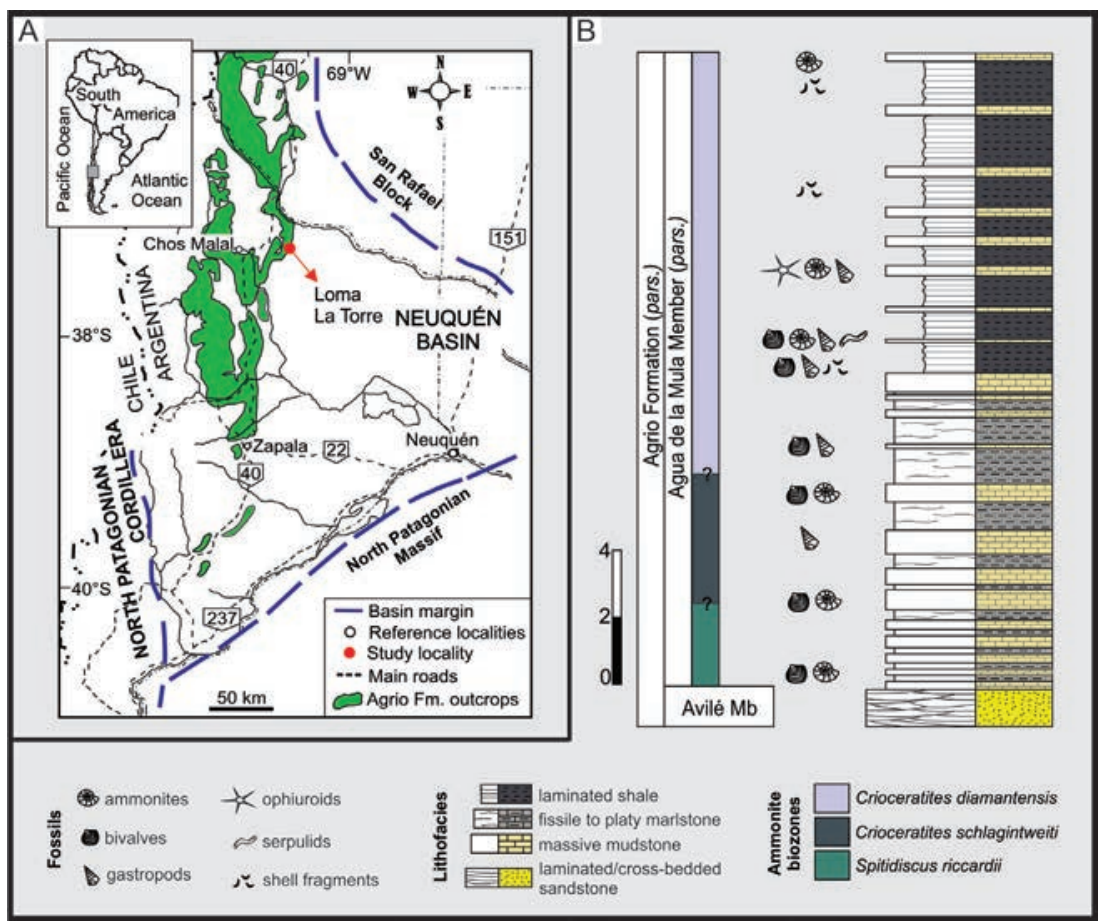

FIG. 1. A. Map of the Neuquén Basin and its location in Argentina and South America. Note the location of the Agrio Formation outcrops and the study site. Modified from Aguirre-Urreta et al. (2007). B. Logged section of the lowermost part of the Agua de la Mula Member, Agrio Formation, in Loma La Torre. Note the ophiuroid-bearing level. Ammonite biozones from AguirreUrreta et al. $(2007,2015)$.

\section{Material and methods}

The logged section included here (Fig. 1B) comprises only the lowermost part of the Agua de la Mula Member, i.e., the interval of interest where the ophiuroid-bearing level is found. Three specimens preserved on slabs were examined under scanning electron and light microscopy. For SEM images, a microscope FEI Quanta 200 was used after standard sample preparation (thin gold coat). Light photographs were taken with a Leica M165C microscope and DFC295 camera and combined using Combine ZP stacking software. The studied samples are housed in the Collection of the Área de Paleontología (Departamento de Ciencias Geológicas, Facultad de Ciencias Exactas y Naturales, Universidad de Buenos Aires) under the prefix CPBA with the numbers 20455.1, 20455.2 and 20455.3. The specimens from the type locality (Kimmeridgian of France) are housed in the palaeontological collection of the Luxembourg Natural History Museum under the prefix MnhnL. Morphological terminology follows Stöhr et al. (2012) for skeletal plates, and Thuy and Stöhr (2011) for features of lateral arm plates. Higher-level classification is adopted from O'Hara et al. (2017).

\section{Results}

\subsection{Systematic paleontology}

Order Amphilepidida O'Hara et al., 2017 Suborder Ophionereidina O'Hara et al., 2017 Superfamily Ophionereidoidea Ljungman, 1867 Family Ophionereididae Ljungman, 1867

Diagnosis. Granules along the genital slit, extending onto disc edge. Accessory dorsal arm plates (Ophionereis). Scale-like, flat, oval to round tentacle scales. Tooth sockets dorsally as large fenestrations with septum. Arm spine articulation horse-shoe shaped, with parallel dorsal and ventral lobes proximally separated by vertical row of knobs or merged by ribbed border, framing nerve and muscle openings of almost equal size. Internal of 
lateral arm plate with large pore close to the dorsal edge of the tentacle pore excavation, at the ventral tip of a large ridge along the inner proximal edge that bends ventro-distalwards. Vertebrae with distally protruding dorsal keel and proximal dorsal groove (from O’Hara et al., 2018).

\section{Genus Ophiopetra Hess in Enay and Hess, 1962}

Diagnosis. Small species. Disc with granules on both sides (including radial shields). Granules covering small imbricated disc scales. Radial shields and genital plates articulate with two condyles and a facet present in both the radial shield and the corresponding genital plate. Radial shields of moderate width, those of the same radius do not touch each other. Oral plates without large, wing-like flange. Double peristomial plates. Approximately six oral papillae contiguous on each side. Probably no tooth papillae. Teeth blunt, not very strong. Adoral shields meeting at proximal edge of oral shield. Arm spines in groups of three, erect, slightly longer than one arm segment. Ventral arm plates pentagonal, longer than wide, contiguous only on the proximal half of the arm. Dorsal arm plates triangular, with a strongly convex distal edge. Tentacles pores on almost the entire length of the arms, two tentacle scales per pore. Vertebrae with zygospondylous articulation (from Hess in Enay and Hess, 1962).

\section{Ophiopetra sp.}

(Figs. 2-5)

Description. CPBA 20455.1 (Figs. 2A, 2C-D, 2F, 4A-F, 5A-C). Deformed disc. Dorsal disc scales not discernible due to insufficient preservation; small granules are visible. Radial shields may be represented by two poorly preserved oval plates (Fig. 2D). Connection between the arms and the central disc is clear in two arms (Fig. 2A). Lateral arm plates stout, subquadrangular to subrectangular with distal edge convex and proximal and lateral edges mostly straight (Fig. 2F). Height/length ratio is approximately 0.62 in proximal lateral arm plates (Figs. 4E and F) while distal ones (Figs. 4A, C and $\mathrm{D}$ ) are elongated (height/length $=0.30$ ). One or two horseshoe-shaped arm spine articulations per lateral arm plate (Figs. 5A, B and C). Arm spines smooth and probably conical with a maximum preserved length $2 / 3$ as long as one arm segment
(Figs. 4E and F). Dorsal arm plates subtriangular with convex distal edge, acute proximal edge and straight to slightly convex lateral edges (Figs. 4C and D). Ventral arm plates subrectangular with concave lateral edges, acute proximal edge and pointed to slightly convex distal edge (Figs. 4A and B). Only one elongated tentacle scale is preserved (Fig. 4A). On all observable arm segments, lateral arm plates separate dorsal and ventral arm plates (Fig. 2F). Outer surface of lateral and dorsal arm plates with coarse tubercles (Figs. 4C and E).

CPBA 20455.2 (Figs. 2E, 3A-D, 5D). The specimen shows a faint outline of the disc, which is circular, approximately $3.5 \mathrm{~mm}$ in diameter (Fig. 2E). Oral plates long, relatively slender and slightly curved (Figs. 3A and B). Dental plate and at least one flat subquadrangular tooth are observed (Figs. 3A, $\mathrm{B}$ and $\mathrm{C}$ ). Only one poorly preserved, rod-shaped genital plate (Fig. 3D) and one poorly preserved, much longer than wide/high vertebra are observed (Fig. 5D).

CPBA 20455.3 (Fig. 2B) shows a faint outline of the disc. Five long and slender arms with a maximum preserved length of $9.98 \mathrm{~mm}$, approximately 3 times longer than the disc diameter (Fig. 2B).

\section{Discussion and conclusions}

Although the here-described specimens are rather poorly preserved (with some deformed areas and fragmented pieces), they show some characters of diagnostic value allowing for a placement in a taxonomic context at least to the genus level. Here, the shape of the spine articulations is of particular interest. According to Martynov (2010), Ophionereididae and Ophiochitonidae, which have recently been synonymized (O'Hara et al., 2017), present horseshoe-shaped arm spine articulations. Among the currently known fossil ophiuroid genera, horseshoe-shaped spine articulations were explicitly mentioned for Ophiopetra from the Late Jurassic of France (Hess, 1965a), although the diagnosis of the genus does not include information on the spine articulations (Enay and Hess, 1962) or other characters that are now considered to be diagnostic (Martynov, 2010; Thuy and Stöhr, 2011). Ophiopetra lithographica Hess in Enay and Hess, 1962 is currently the only valid species within this genus (Thuy et al., 2013), and we had the chance to study specimens of O. lithographica from the type locality (Figs. 5E, F). 


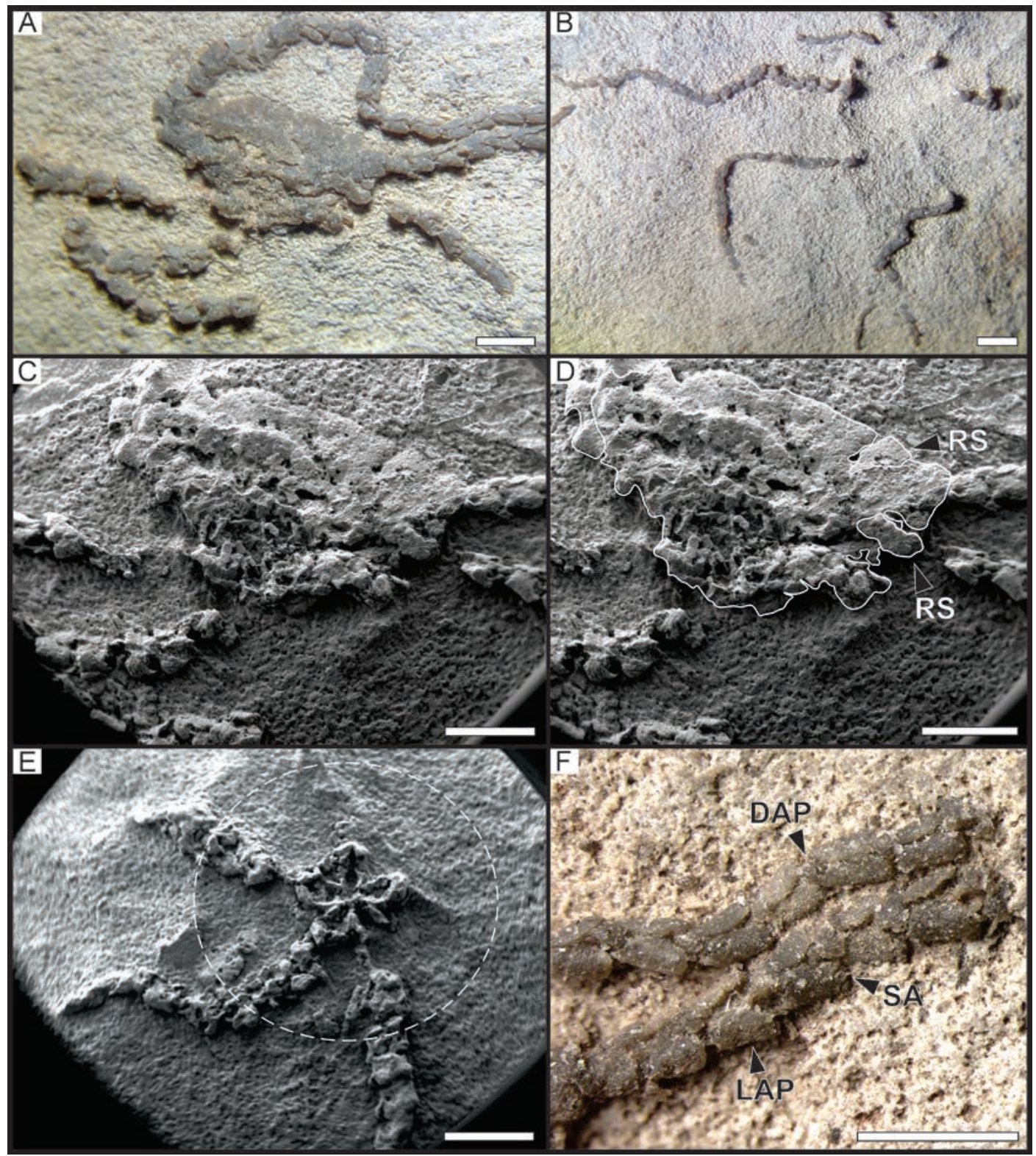

FIG. 2. General view of specimens. A. CPBA 20455.1 with partially deformed disc. Two of the arms in connection with the disc and the other three slightly disconnected. B. CPBA 20455.3. Only the arms are preserved but a faint outline of the disc is visible. C. CPBA 20455.1. Detail of the deformed disc. D. CPBA 20455.1. Detail of C, with drawing of the outline of the disc and position of the radial shields. E. CPBA 20455.2. Part of the disc and proximal portion of three arms. The outline of the disc is marked with a dotted circle. F. CPBA 20455.1. Two arms, showing dorsal arm plates, lateral arm plates and one spine articulation. RS: radial shield; LAP: lateral arm plate; DAP: dorsal arm plate; SA: spine articulation; Scale bars: $1 \mathrm{~mm}$.

Scanning electron microscopy allowed us to confirm that the spine articulations of Ophiopetra lithographica are, indeed, similar to the horseshoe-shaped ones of the material described herein and the ones typical of Ophionereididae in general.
The systematic position of Ophiopetra has been under debate, ever since the erection of the genus (Enay and Hess, 1962). According to the latest classification of the Ophiuroidea, the Ophionereididae include the genera Ophiodoris Koehler, 1904, Paris 


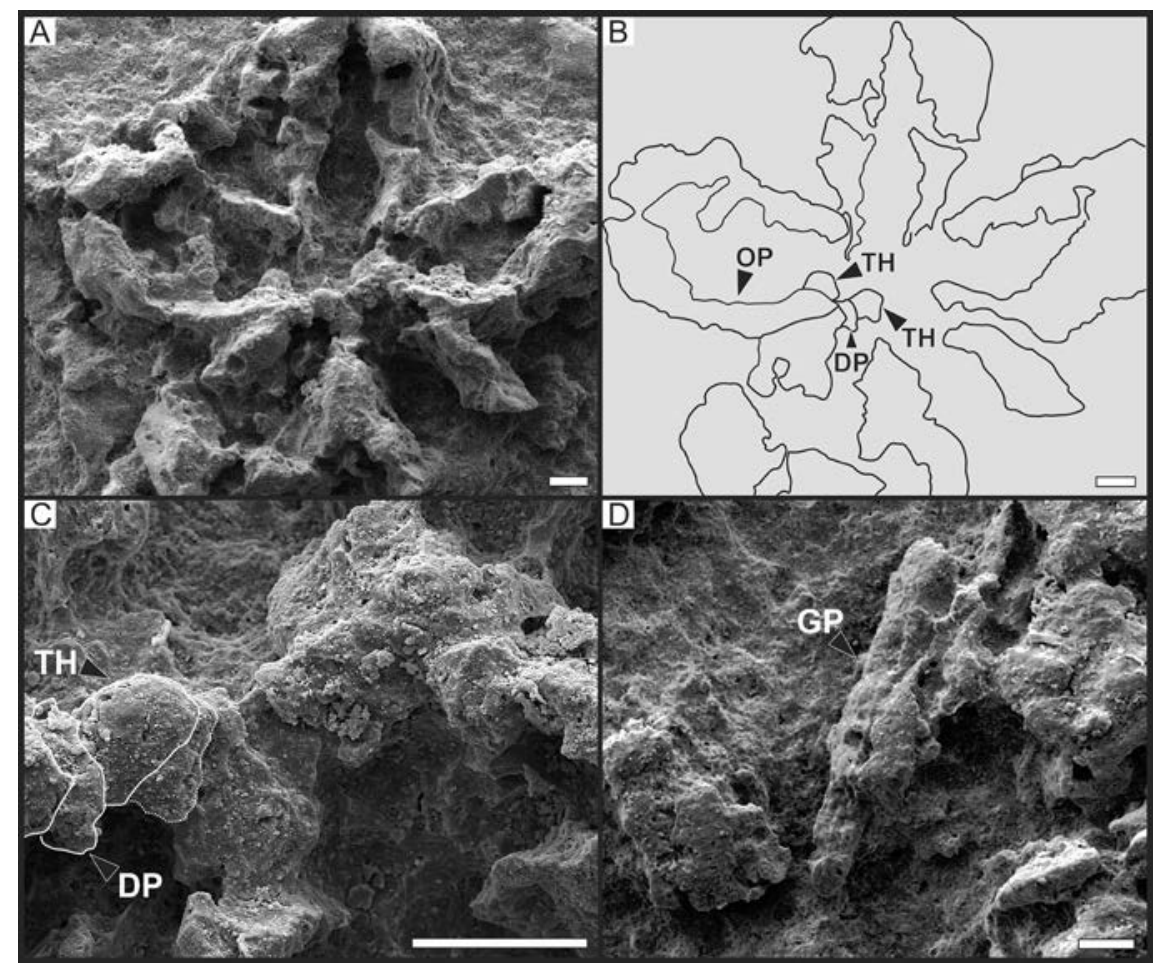

FIG. 3. Details of the disc area. CPBA 20455.2. A. Close up of the oral plates. Note they are long, relatively slender and slightly curved. B. Line drawing of A, detailing oral plates, teeth and a dental plate. C. Detail of A showing teeth and a dental plate. D. Poorly preserved, rod-shaped genital plate. OP: oral plate; TH: teeth; DP: dental plate; GP: genital plate; Scale bars: $100 \mu \mathrm{m}$.

Ophionereis Lütken, 1859, Ophioplax Lyman, 1875, and Ophiochiton Lyman, 1878 (O'Hara et al., 2017, 2018). In Ophiodoris and Ophioplax the lateral arm plates are ornamented with small tubercles (Lyman, 1875; Koehler, 1904; Numberger-Thuy and Thuy, 2015). The lateral arm plates exhibited by the specimens described herein are similar to what is found in Ophiodoris and Ophioplax (Lyman, 1875; Koehler, 1904). However, in the disc ornamentation, the present material differs from Ophiodoris, in which the disc is naked or bears small spines (Koehler, 1904; Fell, 1960), and from Ophioplax which has granules only on the ventral side of the disc (Lyman, 1875; Fell, 1960). In Ophiopetra, in contrast, both sides of the disc are densely covered with granules. We therefore place the here-described specimens in the genus Ophiopetra, also taking into account similarities in the overall shape of the lateral arm plates.

At the moment, Ophiopetra is considered an ophiolepidid (Thuy et al., 2012). In the context of the latest progress in ophiuroid systematics, and thanks to the new insights on the spine articulation microstructure of Ophiopetra lithographica presented herein, we propose a transfer of Ophiopetra to the Ophionereididae.

Given the lack of preserved diagnostic disc characters, these specimens are not assigned to Ophiopetra lithographica. Also, the stratigraphic and palaeo-biogeographic distance to O. lithographica (see below) suggest that the here-described specimens belong to a new species. Considering the poor preservation of the currently known material and the lack of disc characters, however, we prefer not to introduce a new name, as it would be based on a highly incomplete diagnosis.

\subsection{Evidence for paedomorphosis}

Ontogenetic studies on post-metamorphic ophiuroids have recently gained more attention (e.g., Stöhr, 2005; Martynov, 2012; Borges et al., 2015). The geometry and proportions of the ophiuroid skeleton gradually and continually change during growth, which complicates an assignment to an 


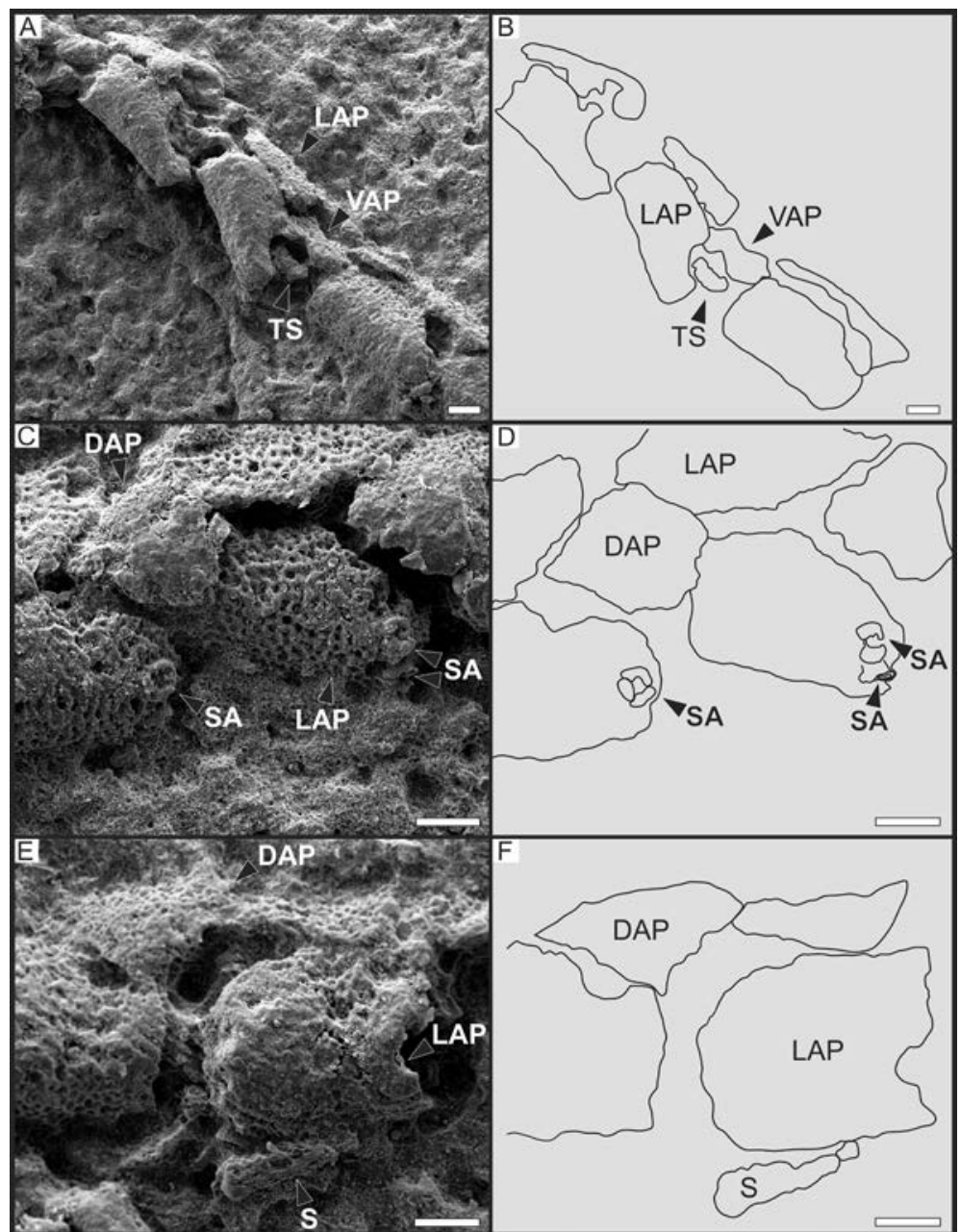

FIG. 4. Articulated arm segments. CPBA 20455.1. A. Ventral side of the arm, showing lateral arm plates, one ventral arm plate and one tentacle scale. B. Line drawing of A. C. Dorso-lateral view of arm showing lateral arm plates, dorsal arm plates and spine articulations. Note the granulated outer surface. D. Line drawing of C. E. Latero-dorsal view of arm showing lateral arm plates, dorsal arm plates and one spine. F. Line drawing of E. LAP: lateral arm plate; VAP: ventral arm plate; TS: tentacle shield; DAP: dorsal arm plate; SA: spine articulation; S: spine; Scale bars: $100 \mu \mathrm{m}$.

ontogenetic stage. Some parts of this material present juvenile traits, e.g., small dorsal plates, relatively elongated arm segments even in proximal position (Martynov et al., 2015), and slightly curved jaws (Stöhr and Martinov, 2016). The vertebra (Fig. 5D) in specimen 20455.2 is much longer than wide/high in a very proximal position of the arm, which is an indicator of juvenile/paedomorphic conditions (Stöhr and Martinov, 2016). However, other characteristics, e.g., the diameter of the disc, are not compatible with juveniles (Webb and Tyler, 1985; Borges et al., 2015; Martynov et al., 2015) but may suggest paedomorphic adults (Stöhr and Martynov, 2016). Hence, the evidence suggests that these ophiuroids are paedomorphic specimens. It is worth to note that this information does not lead to taxonomic uncertainty.

\subsection{Ophiuroid fossil remains in South America and the record of Ophiopetra}

The findings of articulated and/or nearly complete brittle stars in South America are restricted to Devonian appearances (Ruedemann, 1916; Clarke, 1913; Méndez-Alzola, 1938; Melo, 1988; Rehfeld and 


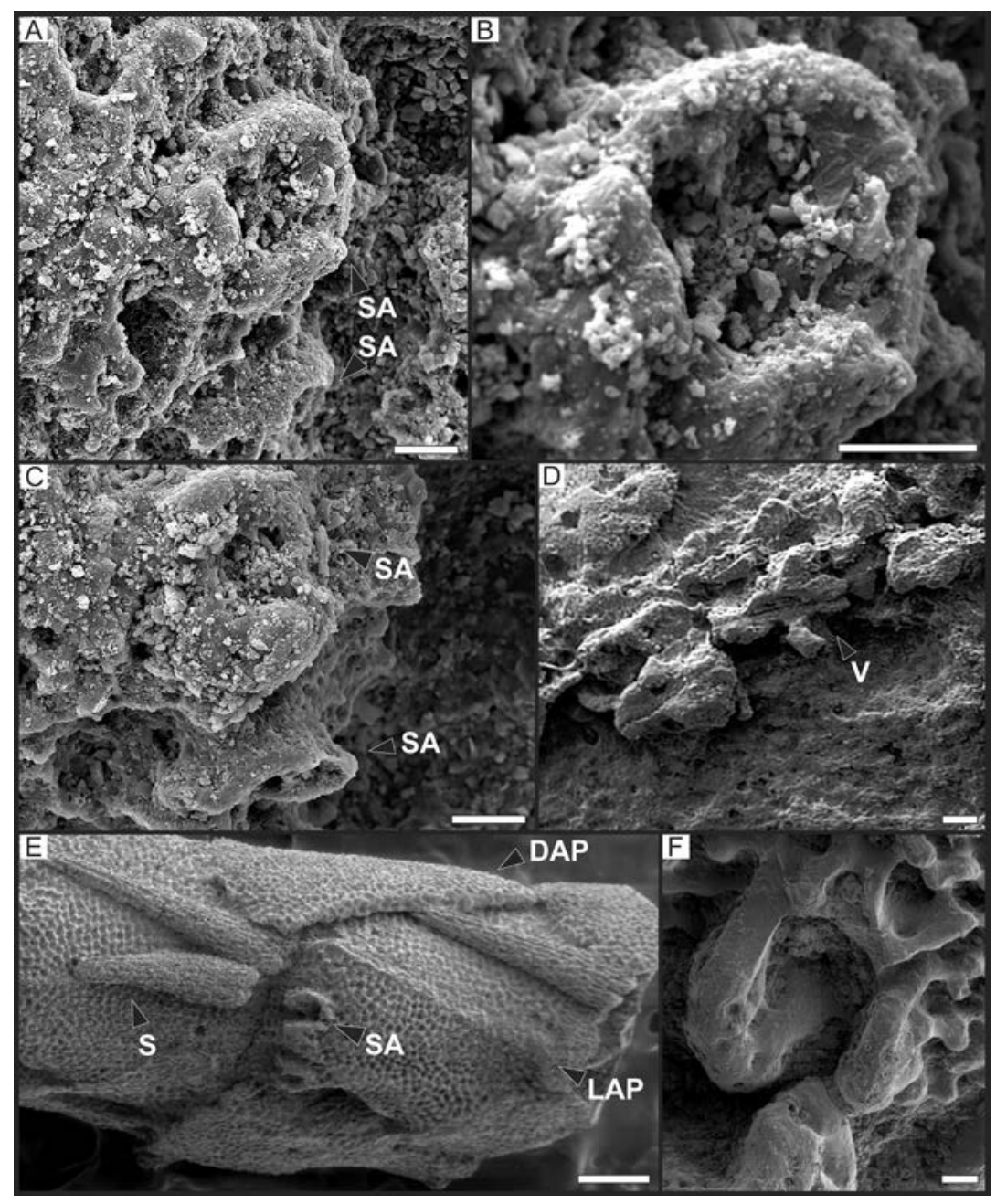

FIG. 5. Spine articulations and a vertebra of the material described herein and specimens of Ophiopetra lithographica from the type locality (Kimmeridgian of France), for comparison. A. CPBA 20455.1. Detail of lateral arm plate with two horseshoe-shaped arm spine articulation. B. CPBA 20455.1. Close up of spine articulation in A. C. CPBA 20455.1. Another example of spine articulations. D. CPBA 20455.2. A poorly preserved, longer than wide/high vertebra. E. MnhnL OPH028. Arm segments of Ophiopetra lithographica. Note the granulated outer surface, the general shape of the arm plates and the spine articulation. F. MnhnL OPH028. O. lithographica. Spine articulation. SA: spine articulation; V: vertebra; DAP: dorsal arm; LAP: lateral arm plate; SA: spine articulation; S: spine; Scale bars: $20 \mu \mathrm{m}$ in A, B and C; $0.1 \mathrm{~mm}$ in D; $100 \mu \mathrm{m}$ in E; $10 \mu \mathrm{m}$ in F.

Mehl, 1989; Haude, 1995, 2010), Permian (Sánchez, 1983) and Cenozoic specimens (e.g., Berry, 1941; Furque and Camacho, 1949; Kutscher et al., 2004; Caviglia et al., 2007; Martínez and del Río, 2008). Isolated remains were reported from Devonian (Rehfeld and Mehl, 1989), Jurassic-Cretaceous (Kietzmann et al., 2014) and Cenozoic (Bertels, 1965) sedimentary deposits. For the Mesozoic of South America, the fossil record of ophiuroids is restricted to trace fossils from the Lower Cretaceous of Argentina and Chile (Bell, 2004; Rodríguez et al., 2007) and isolated ossicles from the deposits of the Tithonian-Valanginian interval in Argentina (Kietzmann et al., 2014). The material presented here includes the first remains of articulated ophiuroids for the Mesozoic of South America.

Ophiopetra lithographica is recorded from the Callovian of Switzerland (Hess, 1963), Kimmeridgian of France (e.g., Bourseau et al., 1991), and Tithonian of Germany (Kutscher and Röper, 1995; Hess, 1999) 
and Austria (Hess, 1965b). Isolated ossicles assigned to Ophiopetra sp. were reported from the Middle Jurassic of Poland (Gedl et al., 2003). Therefore, these specimens also represent the first record of the genus Ophiopetra for the Southern Hemisphere and for the Cretaceous worldwide.

\section{Acknowledgements}

This study was financially supported by ANPCyT (PICT-189) and CONICET (PIP 5960) to M.B. AguirreUrreta (IDEAN-CONICET) and UBACyT Grant (20162018) to P.J. Pazos. A. Caramés and M.B. Aguirre-Urreta (IDEAN-CONICET) are acknowledged for their assistance with the microscope and the ammonoid biozones, respectively. This work has been improved by constructive reviews from $\mathrm{G}$. Bressan, S. Martínez and one anonymous reviewer. We thank the Editorial Team of Andean Geology for their work. This is contribution R-240 of the Instituto de Estudios Andinos don Pablo Groeber.

\section{References}

Aguirre-Urreta, M.B. 2003. Early Cretaceous decapod Crustacea from the Neuquén Basin, west-central Argentina. Contributions to Zoology 72 (2-3): 79-81.

Aguirre-Urreta, M.B.; Rawson, P. 2012. Lower Cretaceous ammonites from the Neuquén Basin, Argentina: a new heteromorph fauna from the uppermost Agrio Formation. Cretaceous Research 35: 208-216.

Aguirre-Urreta, M.B.; Mourgues, F.; Rawson, P.; Bulot, L.; Jaillard, R. 2007. The Lower Cretaceous Chañarcillo and Neuquén Andean basins: ammonoid biostratigraphy and correlations. Geological Journal 42: 143-173.

Aguirre-Urreta, M.B.; Tunik, M.; Naipauer, P.; Pazos, P.; Ottone, E.; Fanning, M.; Ramos, V. 2011. Malargüe Group (Maastrichtian-Danian) deposits in the Neuquén Andes, Argentina. Gondwana Research 19: 482-494.

Aguirre-Urreta, M.B.; Lescano, M.; Schmidtz, M.; Tunik, M.; Concheyro, G.; Rawson, P.; Ramos, V. 2015. Filling the gap: new precise Early Cretaceous radioisotopic ages from the Andes. Geological Magazine 152: 557-564.

Aronson, R. 1989. Brittlestar beds: Low-predation anachronisms in the British Isles. Ecology 70 (4): 856-865.

Bell, C.M. 2004. Asteroid and ophiuroid trace fossils from the Lower Cretaceous of Chile. Palaeontology 47: 5166.

Berry, C.T. 1941. Tertiary ophiurans from Venezuela. Journal of Paleontology 15: 68-70.

Bertels, A. 1965. Noticias sobre el hallazgo de restos de equinodermos en el Paleoceno de General Roca (Pcia. de Río Negro). Ameghiniana 4 (3): 84-99.
Borges, M.; Alitto, R.; Zacagnini Amaral, A. 2015. From baby to adult: ontogenetic series of nine species of Ophiuroidea from Atlantic Southwestern. Revista de Biología Tropical 63 (Suppl. 2): 361-381.

Bourseau, J.-P.; Hess, H.; Bernier, P.; Barale, G.; Buffetaut, E.; Gaillard, C.; Gall, J.C.; Wenz, S. 1991. Découverte d'ophiures dans les calcaires lithographiques de Cerin (Kimméridgien supérieur, Ain, France). Systématique et implications taphonomiques. Comptes Rendus de 1'Académie des Sciences 312: 793-799. París.

Cataldo, C. 2014. The gastropod family Aporrhaidae in the Lower Cretaceous of the Neuquén Basin, West-Central Argentina. Journal of Paleontology 88: 1222-1239.

Caviglia, S.; Martínez, S.; Del Río, C.J. 2007. A new Early Miocene species of Ophiocrossota (Ophiuroidea) from Southern Patagonia, Argentina. Neues Jahrbuch für Geologie und Paläontologie, Abhandlungen 245 (2): 147-152.

Cichowolski, M. 2003. The nautiloid genus Cymatoceras from the Cretaceous of the Neuquén and Austral basins, Argentina. Cretaceous Research 24: 375-390.

Clarke, J. 1913. Fosseis Devonianos do Paraná. Monographias do Serviço e Mineralogico do Brasil 1: 1-353.

Comerio, M.; Fernández, D.E.; Pazos, P.J. 2018. Sedimentological and ichnological characterization of muddy storm related deposits: The upper Hauterivian ramp of the Agrio Formation in the Neuquén Basin, Argentina. Cretaceous Research 85: 78-94.

Dahm, C. 1996. Ökologie und Populationsdynamik antarktischer Ophiuroiden (Echinodermata). Berichte zur Polarforschung 194: 1-289.

Enay, R.; Hess, H. 1962. Sur la découverte d'Ophiures (Ophiopetra lithographica n.g. n.sp.) dans le Jurassique supérieur du Haut-Valromey (Jura méridional). Zeitschrift: Eclogae Geologicae Helvetiae 55: 657-673.

Ewin, T.; Thuy, B. 2017. Brittle stars from the British Oxford Clay: unexpected ophiuroid diversity on Jurassic sublittoral mud bottoms. Journal of Paleontology 81 (4): 781-798.

Fell, H.B. 1960. Synoptic keys to the genera of Ophiuroidea. Zoology Publications from Victoria University of Wellington 26: 1-44.

Fernández, D.E.; Pazos, P. 2012. Ichnology of marginal marine facies of the Agrio Formation (Lower Cretaceous, Neuquén Basin, Argentina) in its type locality. Ameghiniana 49 (4): 505-524.

Fernández, D.E.; Pazos, P. 2013. Xiphosurid trackways in a Lower Cretaceous tidal flat in Patagonia: Palaeoecological implications and the involvement of microbial mats in trace-fossil preservation. 
Palaeogeography, Palaeoclimatology, Palaeoecology 375: 16-29.

Furque, G.; Camacho, H. 1949. El Cretácico Superior de la costa atlántica de Tierra del Fuego. Revista de la Asociación Geológica Argentina 4: 263-297.

Gedl, P.; Kaim, A.; Boczarowski, A.; Kędzierski, M.; Smoleń, J.; Szczepanik, P.; Witkowska, M.; Ziaja, J. 2003. Rekonstrukcja paleośrodwiska sedymentacji środkowojurajskich iłów rudonośnych Gnaszyna (Częstochowa)-wyniki wstępne. Volumina Jurassica 1 (1): 19-28.

Gerdes, D.; Klages, M.; Arntz, W.; Herman, R.; Galéron, J.; Hain, S. 1992. Quantitative investigations on macrobenthos communities of the southeastern Weddell Sea shelf based on multibox corer samples. Polar Biology 12: 291-301.

Haude, R. 1995. Echinodermen aus dem Unter-Devon der argentinischen Praekordillere. Neues Jahrbuch für Geologie und Paläontologie, Abhandlungen 197 (1): 37-86.

Haude, R. 2010. Ophiuroids in the Lower Devonian of the Argentine Precordillera. In Echinoderm Research 2010 (Reich, M.; Reitner, J.; Roden, V.; Thuy, B.; editors). European Conference on Echinoderms, No. 7, University of Göttingen: 46-47. Göttingen.

Hess, H. 1963. Mikropaläontologische Untersuchungen an Ophiuren III: Die Ophiuren aus dem CallovienTon von Liesberg (Berner Jura). Eclogae Geologicae Helvetiae 56: 1141-1164.

Hess, H. 1965a. Trias-Ophiurien aus Deutschland, England, Italien und Spanien. Mitteilungen der bayerischen Staatssammlung für Paläontologie und historische Geologie 5: 151-177.

Hess, H. 1965b. Ophiuren-Reste (Echinodermata) aus den Neuburger Bank-kalken (Mittel-Tithon) des Fränkischen Jura. Mitteilungen der bayerischen Saatssammlung für Paläontologie und historische Geologie 5: 179-184.

Hess, H. 1999. Upper Jurassic Solnhofen Plattenkalk of Bavaria, Germany. In Fossil Crinoids (Hess, H.; Ausich, W.; Brett, C.; Simms, M.; editors). Cambridge University Press: 6-224. Cambridge.

Howell, J.; Schwarz, E.; Spalletti, L.; Veiga, G. 2005. The Neuquén Basin: an overview. Geology Society of London, Special Publications 252: 1-14.

Kerr, T.; Twitchett, R. 2004. Experimental decay and disarticulation of Ophiura texturata: implications for the fossil record of ophiuroids. In Echinoderms: Munchen: Proceedings of the $11^{\text {th }}$ International Echinoderm Conference, Munich, Germany (Heinzeller, T.; Nebelsick, J.H.; editors). CRC Press: 439-446. London.
Kietzmann, D.A.; Palma, R.M.; Riccardi, A.C.; MartinChivelet, J.; López-Gómez, J. 2014. Sedimentology and sequence stratigraphy of a Tithonian-Valanginian carbonate ramp (Vaca Muerta Formation): a misunderstood exceptional source rock in the Southern Mendoza area of the Neuquén Basin, Argentina. Sedimentary Geology 302: 64-86.

Koehler, R. 1904. Ophiures de l'expédition du Siboga. Part 1. Ophiures de mer profonde. In Siboga Expeditie 45a (Weber, M.; editor). E.J. Brill Publisher: 1-176. Leiden.

Kutscher, M.; Röper, M. 1995. Die Ophiuren des "Papierschiefers" von Hienheim (Malm zeta 3, Untertithon). Archaeopteryx 13: 85-99.

Kutscher, M.; Neumann, C.; Nielsen, S.; Reich, M.; Villier, L. 2004. Echinoderms from the Miocene of Chile. In Echinoderms (Heinzeller, T.; Nebelsick, J.; editors). Taylor and Francis Group: 453-456. London.

Lazo, D.; Cichowolski, M.; Rodríguez, D.; AguirreUrreta, M.B. 2005. Lithofacies, palaeoecology and palaeoenvironments of the Agrio Formation, Lower Cretaceous of the Neuquén Basin, Argentina. Geological Society of London Special Publication 252: 295-315.

Lazo, D.; Concheyro, G.; Ottone, E.; Guler, M.; AguirreUrreta, M.B. 2009. Bioestratigrafía integrada de la Formación Agrio en su localidad tipo, Cretácico Temprano de cuenca Neuquina. Revista de la Asociación Geológica Argentina 65 (2): 322-341.

Leanza, H.; Hugo, C.; Repol, D. 2001. Hoja Geológica 3969-I, Zapala, provincia del Neuquén. Servicio Geológico Minero Argentino, Boletín 275: 1-128.

Legarreta, L.; Uliana, M. 1991. Jurassic-Cretaceous marine oscillations and geometry of backarc basin fill, Central argentine Andes. In Sedimentation, Tectonics and Eustasy. Sea level Changes at Active Plate Margins (Mac Donald, D.I.; editor). International Association of Sedimentologists (IAS), Special Publications 12: 429-450.

Legarreta, L.; Uliana, M. 1999. El Jurásico y Cretácico de la Cordillera Principal y la Cuenca Neuquina. 1. Facies sedimentarias. In Geología Argentina. Instituto de Geología y Recursos Minerales (Caminos, R.; editor). Servicio Geológico Minero Argentino, Anales 29: 399-416.

Ljungman, A.V. 1867. Ophiuroidea viventia huc usque cognita enumerat. Öfversigt af Kongliga VetenskapsAkademiens Förhandlingar 23: 303-336.

Luci, L.; Garberoglio, R.; Lazo, D. 2013. Serpulids and other calcareous tube-dwelling encrusting polychaetes from the Early Cretaceous Agrio Formation (Neuquén Basin, Argentina). Geobios 46: 213-224. 
Lütken, C. 1859. Additamenta ad historiam Ophiuridarum. Anden Afdelning. Det kongelige danske Videnskabernes Selskabs Skrifter. 5 Raekke, Naturvidenskabelig og mathematisk Afdelning. 5: 177-271.

Lyman, T. 1875. Zoological Results of the Hassler Expedition. 2. Ophiuridae and Astrophytidae. Illustrated catalogue of the Museum of Comparative Zoology at Harvard College 8 (2): 1-34.

Lyman, T. 1878. Ophiuridae and Astrophytidae of the exploring voyage of H.M.S. Challenger, under Prof. Sir Wyville Thomson, F.R.S. Part 1. Bulletin of the Museum of Comparative Zoology 5: 65-168.

Martin-Medrano, L.; García-Barrera, P. 2013. Análisis del registro fósil de ofiuroideos (Echinodermata) en el Continente Americano. Boletín de la Sociedad Geológica Mexicana 65 (3): 497-509.

Martínez, S.; Del Río, C.J. 2008. A new, first fossil species of Ophioderma Müller and Troschel, 1842 (Echinodermata: Ophiuroidea) (Late Miocene, Argentina). Zootaxa 1841: 43-52.

Martínez, A.V.; Del Río, C.J.; Pérez, D. 2010. A brittle star bed from the Miocene of Patagonia, Argentina. Lethaia 43: 1-9.

Martynov, A.V. 2010. Reassessment of the classification of the Ophiuroidea (Echinodermata), based on morphological characters. I. General character evaluation and delineation of the families Ophiomyxidae and Ophiacanthidae. Zootaxa 2697: 1-154.

Martynov, A. 2012. Ontogenetic Systematics: The Synthesis of Taxonomy, Phylogenetics, and Evolutionary Developmental Biology. Paleontological Journal 46 (8): 833-864.

Martynov, A.; Ishida, Y.; Irimura, S.; Tajiri, R.; O'Hara, T.; Fujita, T. 2015. When Ontogeny Matters: A New Japanese Species of Brittle Star Illustrates the Importance of Considering both Adult and Juvenile Characters in Taxonomic Practice. PLoS One 10 (10): e0139463. doi: 10.1371/journal.pone.0139463.

Melo, J. 1988. The Malvinokaffric realm in the Devonian of Brazil. In Devonian of the World (McMillan, N.J.; Embry, A.F.; Glass, D.J.; editors). Canadian Society of Petroleum Geologists: 669-703. Calgary.

Méndez-Alzola, R. 1938. Fósiles devónicos del Uruguay. Instituto de Geología y Perforaciones, Boletín 24: 1-115.

Numberger-Thuy, L.D.; Thuy, B. 2015. Pliocene deep-sea ophiuroids from the Mediterranean with Western Atlantic affinities. In Progress in Echinoderm Palaeobiology (Zamora, S.; Rábano, I.; editors). Instituto Geológico y Minero de España. Cuadernos del Museo Geominero 19: 125-127. Madrid.
O’Hara, T.; Hugall, A.; Thuy, B.; Stöhr, S.; Martynov, A. 2017. Restructuring higher taxonomy using broad-scale phylogenomics: The living Ophiuroidea. Molecular Phylogenetics and Evolution 107: 415-430.

O’Hara, T.D.; Stöhr, S.; Hugall, A.F.; Thuy, B.; Martynov, A. 2018. Morphological diagnoses of higher taxa of Ophiuroidea (Echinodermata) in support of a new classification. European Journal of Taxonomy 416: 1-35.

Pazos, P.; Fernández, D.E. 2010. Three-dimentionally integrated trace-fossils from-shallow marine deposits in the Lower Cretaceous of the Neuquén Basin: Hillichnus agrioensis isp. nov. Acta Geológica Polonica 60 (1): 105-118.

Pazos, P.; Lazo, D.; Tunik, M.; Marsicano, C.; Fernández, D.E.; Aguirre-Urreta, M.B. 2012. Paeoenvironmental framework of dinosaur trackisites and other ichnofossils in the Early Cretaceous mixed siliciclastic-carbonate deposits in the Neuquén Basin, northern Patagonia (Argentina). Gondwana Research 22: 1110-1124.

Pérez, D.; Fernández, D.E.; Comerio, M. 2011. Primer registro corpóreo articulado de ofiuroideos (Echinodermata: Asterozoa: Ophiuroidea) para el Mesozoico de América del Sur. Ameghiniana 48 (4 Suplemento): R20-R21.

Rehfeld, U.; Mehl, J. 1989. Andinodesma radiata $\mathrm{n}$. gen. n. sp., a grammysiid taxon from the Lower Devonian Catavi-Formation (Bolivia) and its autecological and phylogenetic implications. Paläontologische Zeitschrift 63 (3-4): 263-279.

Rodríguez, D.L. 2007. Equinoideos mesozoicos de las cuencas andinas del centro oeste de Argentina. Tesis Doctoral (Inédito), Universidad de Buenos Aires: 398 p.

Rodríguez, D.L.; Pazos, P.J.; Aguirre-Urreta, M.B. 2007. Cretaceous ophiuroid trace fossils from the Neuquén Basin. In Ichnology at the crossroads: A multidimensional approach to the science of organismsubstrate interactions (Bromley, R.G.; Buatois, L.A.; Mángano, M.G.; Genise, J.F.; Melchor, R.N.; editors). Society of Economic Paleontologists and Mineralogists (SEPM), Special Publication 88: 97-105.

Ruedemann, R. 1916. Account of some new or little known species of fossils mostly from Palaeozoic rocks of New York. Paleontological contributions from the New York State Museum 189: 7-97.

Sánchez, T. 1983. A new Permian ophiuroid, Archaeophiomusium andinum nov sp. from western Venezuela. Geobios 16: 103-107.

Spalletti, L.A.; Poiré, D.G.; Schwarz, E.; Veiga, G.D. 2001a. Sedimentologic and sequence stratigraphic model of a Neocomian marine carbonate siliciclastic ramp: Neuquén Basin, Argentina. Journal of South American Earth Sciences 14: 609-624. 
Spalletti, L.; Poiré, D.; Pirrie, D.; Matheos, S.; Doyle, P. 2001b. Respuesta sedimentológica a cambios de nivel de base en una secuencia mixta clástica-carbonática del Cretácico de la Cuenca Neuquina, Argentina. Revista de la Sociedad Geológica de España 14: 57-74.

Spencer, W.K.; Wright, C.W. 1966. Asterozoans. In Treatise on Invertebrate Paleontology, Part U, Echinodermata 3 (Moore, R.C.; editor). Geological Society of America and University Kansas Press: U4-U107. Lawrence.

Stöhr, S. 2005. Who's who among baby brittle stars (Echinodermata, Ophiuroidea): postmetamorphic development of some North Atlantic forms. Zoological Journal of the Linnean Society 143: 543-576.

Stöhr, S.; Martinov, A. 2016. Paedomorphosis as an Evolutionary Driving Force: Insights from Deep-Sea Brittle Stars. PLoS ONE 11 (11): e0164562.

Stöhr, S.; O’Hara, T.; Thuy, B. 2012. Global diversity of brittle stars (Echinodermata: Ophiuroidea). PLoS ONE 7: 1-14.

Taylor, P.; Lazo, D.; Aguirre-Urreta, M.B. 2009. Lower Cretaceous bryozoans from Argentina: a "by-catch" fauna from the Agrio Formation (Neuquén Basin). Cretaceous Research 30 (1): 193-203.

Thuy, B.; Stöhr, S. 2011. Lateral arm plate morphology in extant brittle stars (Echinodermata) and its application in micropalaeontology. Zootaxa 3013: 1-47.

Thuy, B.; Ishida, Y.; Doi, E.; Kroh, A. 2012. New ophiacanthid brittle stars (Echinodermata: Ophiuroidea) from the Upper Triassic of Japan: first insights into the origin and evolution of an extant deep-sea group. Journal of Systematic Palaeontology 11 (5): 515-530.

Thuy, B.; Marty, D.; Comment, G. 2013. A remarkable example of a Late Jurassic shallow-water ophiuroid assemblage from the Swiss Jura Mountains. Swiss Geological Society 106: 409-426.

Thuy, B.; Gale, A.; Stöhr, S.; Wiese, F. 2014. Shallow-water brittle-star (Echinodermata: Ophiuroidea) assemblages from the Aptian (Early Cretaceous) of the North Atlantic: first insights into bathymetric distribution patterns. Gottingen Contributions to Geoscience 77: 163-182. Vergani, G.; Tankard, A.; Belotti, H.; Welsink, H. 1995. Tectonic evolution and paleogeography of the Neuquén Basin, Argentina. In Petroleum Basins of South America (Tankard, A.J.; Suárez Soruco, R.; Welsink, H.J.; editors). American Association of Petroleum Geologists, Memoir 62: 383-402.

Weaver, C. 1931. Paleontology of the Jurassic and Cretaceous of West Central Argentina. Memoirs of University of Washington 1: 1-469.

Webb, C.; Tyler, P. 1985. Post-larval development of the common north-west European brittle stars Ophiura ophiura, O. albida and Acrocnida brachiata (Echinodermata: Ophiuroidea). Marine Biology 89 (3): 281-292.

Zapata, T.; Folguera, A. 2005. Tectonic evolution of the Andean Fold and Thrust Belt of the southern Neuquén Basin, Argentina. Geological Society of London, Special Publications 252: 37-56.

Manuscript received: January 18, 2018; revised/accepted: September 27, 2018; available online: February 04, 2019. 